\title{
Hibridismos e ressignificações nos gêneros cinematográficos
}

\author{
Cyntia Gomes Calhado
}

\author{
SUPPIA, Alfredo (org.). \\ Gêneros cinematográficos \\ e audiovisuais: perspectivas \\ contemporâneas \\ Bragança Paulista: Margem \\ da Palavra, 204 p., 2016.
}

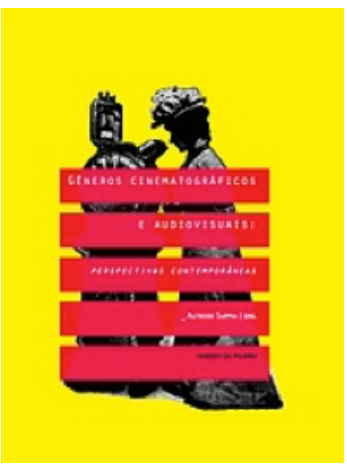

Resumo: Alinhado aos esforços dos estudos contemporâneos que procuram abordagens teóricas mais complexas para lidar com produções audiovisuais híbridas, este livro reflete sobre eventuais novos gêneros ou gêneros revisitados e apresenta métodos e perspectivas mais apropriados à análise desses fenômenos.

Palavras-chave: gêneros cinematográficos contemporâneos; hibridismo genérico; teoria do cinema.

Abstract: Hybridity and new meanings in film genres - Aligned to the efforts of the contemporary genre studies towards the complexification of the theoretical approaches to deal with hybrid audiovisual productions, this book aims to reflect about eventual new genres or revisited genres and to propose methods and perspectives more appropriated to analyse these phenomena.

Keywords: contemporary film genre; genre hybridity; cinema theory.

A coletânea Gêneros cinematográficos e audiovisuais: Perspectivas contemporâneas reúne oito ensaios que abordam tópicos atuais nos estudos de gêneros audiovisuais, 
estabelecendo pontes com a literatura e os estudos feministas. A edição do volume preenche uma lacuna de publicações sobre o assunto no Brasil. Tal escassez pode ser interpretada como reflexo do fato do campo dos estudos de gêneros ser recente e frequentemente subestimado pela academia brasileira, como o próprio organizador, Alfredo Suppia, destaca. Parte da pesquisa de cinema aqui realizada parece ainda reproduzir clivagens entre cinema de autor e de gênero, experimental e comercial, há muito superadas pelas teorias audiovisuais contemporâneas.

O ensaio de abertura é Feminismo, Western e o filme Uma balada para Jo, de Barry Grant. Para situar o diferencial desse longa entre os westerns, Grant localiza dois períodos fundamentais para o revisionismo dos gêneros. A primeira renovação estética acontece na Nova Hollywood dos anos 1970, encabeçada por Steven Spielberg, Martin Scorsese, Brian de Palma, George Lucas e Francis Ford Coppola. Os filmes desta notável safra revelam uma autoconsciência ao operar dentro das tradições hollywoodianas para as reinventar. Outro marco está nos anos 1990, que reúne produções dedicadas à abertura dos gêneros a representações de raça e formações identitárias mais progressistas. É o caso de Uma balada para Jo, que se vale das convenções de um gênero tipicamente masculino para criticar seu patriarcalismo. O gesto autoral (e político) do filme está em subverter o cânone genérico, transformando-o em um filme de mulher. Trata-se de uma apropriação das formas de cultura de massa para criticar uma maneira de fazer cinema de dentro, ao invés de buscar a oposição com desafios experimentais ou brechtianos para confrontar o espectador. Em sua análise, Grant situa a potência de uma vasta produção que passa muitas vezes despercebida pela apreciação crítica e acadêmica de orientação anticomercial.

Western e Cangaço: influências e aproximações, texto de Marcelo Vieira, realiza nova incursão ao western para identificar traços comuns entre o gênero norte-americano e seu correspondente nacional, o cangaço, como a presença da dicotomia entre civilização e selvageria.

A representação da mulher é novamente abordada em Mulheres em crise: o casamento e o divórcio na ficção científica dos anos 1950, de Gabriel Carneiro, em que são ressaltados os discursos progressistas de $A$ mulher de 15 metros (Nathan Juran, 1958) e Casei-me com um monstro (Gene Fowler Jr., 1958). Em outra abordagem de gêneros identitários e cinematográficos, Gilberto Sobrinho traz documentários em vídeo feministas. Desta forma, Questões de gêneros: vídeos, documentários e mulheres no Brasil propõe uma leitura que aproxima a realização audiovisual e os movimentos sociais.

Em Realismo(s) e cinema(s) de ficção científica: uma introdução ao debate, Alfredo Suppia examina ficções científicas realistas no sentido de sustentar que o realismo pode contribuir para um "efeito de ficção científica". Apesar do objeto de análise ser um gênero específico, as considerações do autor podem beneficiar investigações de produções realistas que flertam com o cinema de gênero, fenômeno que se intensifica sobretudo entre filmes recentes de caráter autoral. 
As transformações do musical são o assunto de Cantar, dublar, chorar: releituras modernas do musical hollywoodiano clássico, de Pedro Guimarães. Contrariando a ideia de que filmes de gênero são formalmente conservadores, o autor argumenta como os musicais modernos utilizam a narrativa como pretexto para operações formais. Desta forma, reflexividade, formalismo e maneirismo tornam-se o foco de diretores empenhados em reler o musical. Aspectos que recobrem estes filmes de significativo interesse artístico, como demonstram os títulos analisados, entre eles Uma mulher é uma mulher (1961) e O demônio das onze horas (1965) de Jean-Luc Godard.

Filme histórico e generificação no cinema argentino (1966-1973), de Ignacio Dávila, relaciona o cinema histórico e os gêneros. A opção por uma visão dinâmica dos gêneros, com estabilizações, mutações e hibridações, é exemplo de uma abordagem teórica renovada neste campo em oposição às classificações estanques que estigmatizaram certo tipo de análise na área. Já em Um mundo de livros e filmes: anotações sobre o recente cinema juvenil brasileiro, Zuleika Bueno se debruça sobre filmes juvenis contemporâneos procurando evidenciar como eles buscam diálogo com a literatura, de maneira a contribuir para a construção de subjetividades de jovens espectadores.

Em linhas gerais, o interesse do livro está em agregar diversas propostas de abordagem dos gêneros audiovisuais, a maioria realizada por pesquisadores brasileiros, que têm em comum uma concepção renovada desse campo de estudos. Os textos revelam que os gêneros são um vetor profícuo de pesquisas, inclusive por acolher produções comerciais que poucas vezes são frequentadas pela academia brasileira. Em consonância com as análises contemporâneas em âmbito mundial, os gêneros aqui são lidos como contratos comunicacionais que buscam um diálogo lúdico com o espectador.

O conceito de dispositivo representacional também aparece nas reflexões empreendidas no sentido de propor que, distante da concepção de que filmes de gênero constituem mero entretenimento, eles articulam simbolicamente diversos aspectos da realidade, inclusive os políticos e sociais. Não podemos deixar de destacar também os vários longas elencados, cujos aspectos formais são tomados como matéria- prima para a criação autoral. Perante tal lacuna editorial, espera-se um volume maior de publicações neste segmento, já que, além dos pesquisadores reunidos nesta obra, há outros desenvolvendo trabalhos em direção semelhante.

Cyntia Gomes Calhado é doutoranda em Comunicação e Semiótica pela PUC-SP e professora do curso de Rádio e TV no FIAM-FAAM Centro Universitário.

cyntia.calhado@gmail.com 